\section{Dinucleotide repeat polymorphism in the human angiotensinogen gene}

Yu.V.Kotelevtsev +, E.Clauser, P.Corvol and F.Soubrier* INSERM, U-36, Collège de France, 3 Rue d'Ulm, 75005 Paris, France

Source and Description of Clone: $\lambda$ charon 4A M49A clone containing the last $3^{\prime}$ exon of the human angiotensinogen gene (1). A $2.5 \mathrm{~kb}$ PstI fragment of M49A was subcloned in Bluescript SK II vector and nucleotide sequences flanking the (CA) 15 repeat were determined (EMBL accession number: X62854). PCR primers were designed using the OLIGO program (2).

PCR Primers:

Ang5: 5'TAGATCTCTCAGCTATTACAAGG 3' (CA strand) Ang6: 5'GTTTCAGAGAAACTGACCTGTGG 3' (GT strand)

Polymorphism: Allelic fragments were resolved on 5\% denaturing polyacrylamide gels. Length of PCR products and frequencies of alleles determined from 100 unrelated European caucasians were:

$\begin{array}{llllll}\text { allele } & \text { length (nt) } & \text { freq. } & \text { allele } & \text { length } & \text { freq. } \\ \text { A1 } & 133 & .005 & \text { A7 } & 121 & 0.40 \\ \text { A2 } & 131 & .02 & \text { A8 } & 119 & .065 \\ \text { A3 } & 129 & .03 & \text { A9 } & 117 & .13 \\ \text { A4 } & 127 & .03 & \text { A10 } & 115 & .035 \\ \text { A5 } & 125 & .09 & \text { A11 } & 113 & .025 \\ \text { A6 } & 123 & .17 & & & \end{array}$

Heterozygosity $75 \%$.

Chromosomal Localization: Angiotensinogen gene has been mapped to $1 \mathrm{q} 42-q 43$ (3).

Mendelian Inheritance: Co-dominant Mendelian inheritance was observed in 85 informative families with 170 children.

PCR Conditions: PCR was performed in a total volume of 20 microliters with $200 \mathrm{ng}$ of genomic DNA, 8 pmoles of each primer, $2 \mathrm{mM} \mathrm{MgCl}_{2}, 200 \mathrm{mM} \mathrm{dNTP}, 50 \mathrm{mM} \mathrm{KCl}, 5 \mathrm{mM}$ Tris- $\mathrm{HCl}, \mathrm{pH} 8.3,0.01 \%$ gelatin, $0.5 \mathrm{U}$ Taq polymerase (Boehringer). Primer Ang5 was $5^{\prime}$ end labeled with ${ }^{32} \mathrm{P} \gamma$-ATP with the resulting specific activity $0.1-0.05 \mu \mathrm{Ci} / \mathrm{pmol}$. Amplification was for 35 cycles with denaturation at $94^{\circ} \mathrm{C} 1 \mathrm{~min}$, annealing at $55^{\circ} \mathrm{C} 1 \mathrm{~min}$, extension $72^{\circ} \mathrm{C} 2 \mathrm{~min}$. PCR products were heat denatured in $95 \%$ formamide, resolved on $5 \%$ sequencing gels, and autoradiographed on Amersham MP film.

References: 1) Gaillard,I., Clauser,E. and Corvol,P. (1989) DNA 8, 87-99. 2) Rychlik,W. and Rhoads,R.E. (1989) Nucl. Acids Res. 17, 8543-8551. 3) Isa,M.N., Boyd,E., Morrison,E., Harrap,S., Clauser,E. and Connor,J.M. (1990) Genomics 8, $598-600$.

\section{A microsatellite polymorphism at the D3S11 locus}

\author{
P.M.Brett, G.Melmer and H.M.D.Gurling
}

Molecular Psychiatry Laboratory, Department of Academic Psychiatry, University College and Middlesex School of Medicine, Riding House Street, London, W1N 8AA, UK

Source/Description: A human genomic library in EMBL3 was screened with a human repeat free fragment probe of E41 at locus D3S11 (1). Three steps of chromosome walking identified a clone, lambda $\mathrm{E} 41-31$, which is approximately $30 \mathrm{~kb}$ from the original probe. One HaeIII fragment of lambda E41-31, subcloned in M13, hybridised to poly(dC-dA). Sequencing of this subclone identified a (GT) n repeat which detects 7 alleles. The subclone was designated E41-31.13GT. Flanking sequences were used to design PCR primers to amplify the repeat sequence.

PCR Primers:

E41-31.13 1 5'-CAAACTTTCCACAGTATCGTTC-3' E41-31.13 2 5'-GTTTCCTTGAGAAGAATGGAGC-3'

Frequency: Estimated from 52 chromosomes of unrelated European Caucasians.

$\begin{array}{lll} & \text { E41-31.13GT } & \\ \text { Allele } & \text { Size (nt) } & \text { Frequency } \\ \text { B1 } & 147 & 0.14 \\ \text { B2 } & 145 & 0.12 \\ \text { B3 } & 143 & 0.23 \\ \text { B4 } & 141 & 0.14 \\ \text { B5 } & 139 & 0.17 \\ \text { B6 } & 137 & 0.05 \\ \text { B7 } & 135 & 0.15 \\ \text { Heterozygosity }=93 \% \text { PIC }=0.88 & \end{array}$

Heterozygosity $=93 \%$ PIC $=0.88$

Chromosomal Localisation: Localised to 3p14-p21 (1).

Mendelian Inheritance: Co-dominant segregation was observed in 6 two or three generation families.

PCR Conditions: PCR is performed in $\mathbf{1 2 . 5 \mu l}$ containing: $\mathbf{5 0}$ ng DNA, 12.5 pmoles of each primer, $1.0 \mathrm{mM} \mathrm{MgCl}_{2}, 10 \mathrm{mM}$ Tris-Cl pH 8.3, $50 \mathrm{mM} \mathrm{KCl}, 25 \mu \mathrm{M}$ dATP and $200 \mu \mathrm{M}$ of other dNTPs, 1 unit Taq polymerase (Perkin-Elmer/Cetus), $0.01 \%$ gelatin and $0.5 \mu \mathrm{l}$ of ${ }^{35} \mathrm{~S}-\mathrm{dATP}$ at $500 \mathrm{Ci} / \mathrm{mmol}$ (Dupont). Amplification is for 35 cycles with denaturation at $94^{\circ} \mathrm{C}$, annealing at $57^{\circ} \mathrm{C}$ and extension at $72^{\circ} \mathrm{C}$, all for 1 minute each.

Acknowledgements: This work was supported by the Clinical Research and Development Committee (Middlesex Hospital), Medical Research Council and Merck, Sharpe \& Dohme. The original E41 clone was a gift from Dr Dietzsch.

Reference: 1) Dietzsch,E. et al. (1986) Nucl. Acids Res. 14, 8698.

\footnotetext{
* To whom correspondence should be addressed

${ }^{+}$On leave from the All-Union Cardiological Research Center, 121552

Moscow, USSR
} 